\title{
Spontaneous asymptomatic rupture of pseudocyst into stomach
}

\author{
Gopal Sharma, ${ }^{1}$ Shreyash Rai, ${ }^{2}$ Pankaj Kumar Garg ${ }^{2}$
}

'Department of Urology, Postgraduate Institute of Medical Education and Research, Chandigarh, Punjab, India

${ }^{2}$ Department of Surgery, University College of Medical Sciences and GTB Hospital, New Delhi, India

\section{Correspondence to} Dr Gopal Sharma, gopal.26669192@gmail.com

Accepted 11 September 2018

\section{DESCRIPTION}

A 27-year-old woman presented with complaints of pain in the epigastric region radiating to back for 20 days. She was treated initially at local hospital and was diagnosed as acute pancreatitis as her amylase and lipase levels were $>1000 \mathrm{U} / \mathrm{mL}$. She was managed with analgesics and intravenous fluids and was discharged in 4 days. She then presented to our emergency, with complaints of epigastric pain, awareness of lump in the epigastric region and non-passage of stool or flatus for past 3 days. She also gave history of fever and multiple episodes of bilious vomiting. Patient denied previous history of similar episodes in past and is non-alcoholic. On abdominal examination, a lump of size $20 \times 15 \mathrm{~cm}$ was palpable in the epigastric region extending into the umbilical region. On ultrasonogram abdomen, a cystic swelling was seen along with multiple gall stones in the gall bladder. Contrast-enhanced CT (CECT) abdomen was suggestive of a large cystic lesion with air-fluid levels occupying hepatoduodenal ligament lying anterior to the stomach and compressing anterior wall of stomach and duodenum (figure 1). A nasogastric tube was placed that drained around $800 \mathrm{~mL}$ bilious output on first day. Next morning, the nature of nasogastric output changed to purulent, and the lump disappeared. The following evening, the patient passed stool and flatus and underwent upper GI endoscopy the next day, which depicted a fistulous opening on the anterior wall of stomach with active pus discharge (figure 2). At 6 months of follow-up, patient is asymptomatic and doing well.

Pancreatic pseudocysts are cystic cavity lined by fibrous or granulation tissue containing amylase rich pancreatic juice with or without pancreatic

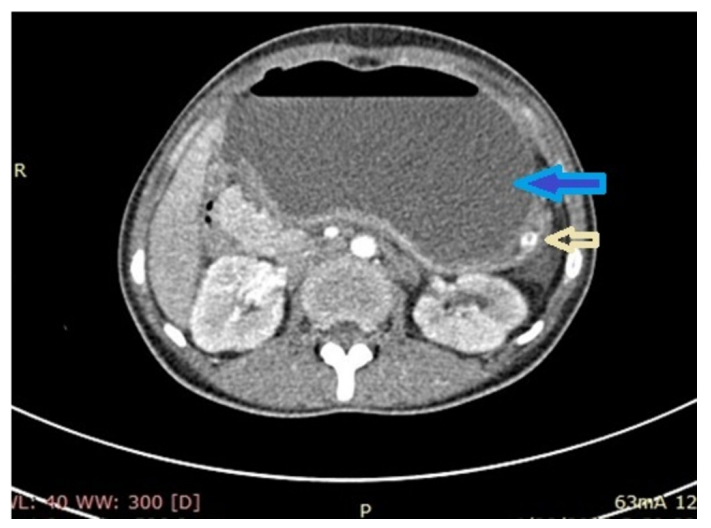

Figure 1 Contrast-enhanced CT abdomen shows large cystic cavity with air-fluid levels (blue solid arrow) and compressed anterior wall of stomach with nasogastric tube in situ (yellow arrow).

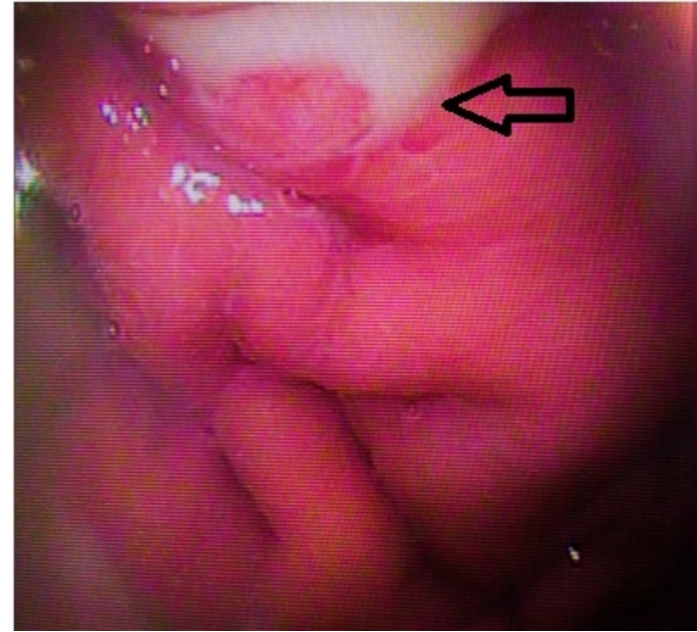

Figure 2 Endoscopic view of stomach: depicting site of fistula between pseudocyst and anterior wall of stomach; active pus discharge can be seen from fistula site marked with arrow.

duct communication. They have been defined by Atlanta classification as 'an encapsulated collection of fluid with a well defined inflammatory wall usually outside the pancreas with minimal or no necrosis'. On CECT, they appear as well-defined, well-circumscribed cavities containing homogeneous fluid density. ${ }^{1}$ Spontaneous rupture of a pseudocyst occurs in less than $3 \%$ of the cases. Sites of drainage include oesophagus, stomach, duodenum, small intestine, colon, peritoneal cavity, portal vein, splenic vein, retroperitoneum, pleural cavity, pericardium or bile duct. Most of these ruptures are associated with acute abdominal pain, gastrointestinal bleeding or sepsis.

Although the gastric communication was clearly evident on upper GI endoscopy, the evidence of gastric fistula can be made out on CECT abdomen as well (figure 1). Air-fluid levels seen in the pseudocyst cavity, close abutment and compression of the anterior wall of the stomach by pseudocyst point towards possibility of communication with hollow viscous. Several mechanisms of rupture of pseudocysts have been proposed such as: raised intracystic pressure, gradual dissolution of the wall of the cyst by pancreatic enzymes that are activated by enterokinase following a fistulous communication with the bowel, increased intra-abdominal pressure and minor abdominal trauma. ${ }^{23}$

More than half of the patients with pseudocysts do not need any intervention for these cysts. Spontaneous resolution of a cyst depends on the size, 


\section{Learning points}

Patients with asymptomatic, uncomplicated, stable or decreasing pseudocysts in size can be observed.

- Symptomatic, complicated and unstable patients with increasing pseudocyst size need an intervention in the form of percutaneous, endoscopic or surgical drainage.

- Conservative management seems appropriate in cases of silent, spontaneous, internal drainage, as in the present patient. However, one must remain cautious to detect complications early.

duration, wall thickness, communication of the cyst with pancreatic duct and associated pancreatic duct stricture. ${ }^{4}$

Contributors GS was involved in the conception, design of the study, acquisition of data, data analysis and the drafting of the manuscript. SR was involved in acquisition of data, data analysis and the drafting of the manuscript. PKG was involved in the conception, design of the study, revision and approval of the final version of the manuscript.

Funding The authors have not declared a specific grant for this research from any funding agency in the public, commercial or not-for-profit sectors.

Competing interests None declared.

Patient consent Obtained.

Provenance and peer review Not commissioned; externally peer reviewed.

\section{REFERENCES}

1 Banks PA, Bollen TL, Dervenis C, et al. Classification of acute pancreatitis--2012: revision of the Atlanta classification and definitions by international consensus. Gut 2013;62:102-11.

2 Littmann R, Pochaczevsky R, Richter RM. Spontaneous rupture of a pancreatic pseudocyst into the duodenum. Arch Surg 1970;100:76-8.

3 Mergl V. Internal drainage of a perforated pancreatic pseudocyst. Int Surg 1971;55:187-91.

4 Andrén-Sandberg A, Dervenis C. Pancreatic pseudocysts in the 21st century. Part II: natural history. JOP 2004;5:64-70.

Copyright 2018 BMJ Publishing Group. All rights reserved. For permission to reuse any of this content visit

http://group.bmj.com/group/rights-licensing/permissions.

BMJ Case Report Fellows may re-use this article for personal use and teaching without any further permission.

Become a Fellow of BMJ Case Reports today and you can:

- Submit as many cases as you like

- Enjoy fast sympathetic peer review and rapid publication of accepted articles

- Access all the published articles

- Re-use any of the published material for personal use and teaching without further permission

For information on Institutional Fellowships contact consortiasales@bmjgroup.com

Visit casereports.bmj.com for more articles like this and to become a Fellow 